\title{
Temporal Changes in $\beta$-Tubulin and Neurofilament mRNA Levels after Transection of Adult Rat Retinal Ganglion Cell Axons in the Optic Nerve
}

\author{
Lisa McKerracher, Charles Essagian, and Albert J. Aguayo \\ Centre for Research in Neuroscience, Montreal General Hospital Research Institute and McGill University, Montreal, \\ Quebec, Canada H3G 1A4
}

\begin{abstract}
Axons of adult mammalian retinal ganglion cells (RGCs) do not regenerate spontaneously after injury in the optic nerve and show a persistent decrease in the rate of transport of tubulin and neurofilament proteins. To investigate further the expression of cytoskeletal proteins in these axotomized CNS neurons, mRNA levels of $\beta$-tubulin and the $150 \mathrm{kDa}$ neurofilament subunit (NF-M) were measured after interrupting the optic nerve $9 \mathrm{~mm}$ from the eye. Northern blots of RNA extracted from whole retinas after optic nerve transection showed that the total level of both of these mRNAs fell after injury. To determine if this decrease was a result of the death of axotomized RGCs or reflected changes in individual neurons, RNA probes were hybridized to radial cryostat sections of normal and axotomized retinas from $1 \mathrm{~d}$ to 6 months after injury. Grain counts revealed two trends of tubulin expression in RGCs. An early increase in tubulin mRNAs in the axotomized RGCs was followed by a later decrease. Such an increase in tubulin mRNA levels has been correlated with regenerative growth in other neurons. By 1 week after injury, the $\beta$-tubulin mRNA levels decreased to $70 \%$ of the control value. Moreover, the time of this fall coincided with the onset of a marked slowing of cytoskeletal transport that follows injury in the optic nerve. In contrast, NF-M mRNA levels dropped immediately after axotomy, and remained at $80 \%$ of the control level. It is suggested that the transient increase in tubulin mRNAs may reflect an early regenerative response whose persistence depends on further growth cone interactions with the substrate.
\end{abstract}

[Key words: microtubules, cytoskeleton, axotomy, CNS, regeneration, slow axonal transport, gene expression]

Certain changes in the cellular expression of cytoskeletal proteins correlate with axonal regrowth after injury (for reviews, see Grafstcin, 1986, 1991). When axons of a peripheral nerve are transected and allowed to regrow, tubulin protein levels rise substantially and there is an enhanced expression of specific

Received Aug. 28, 1992; revised Nov. 27, 1992; accepted Dec. 28, 1992.

We extend our thanks to Paul Jones for helping us devclop the in situ hybridization technique, and for many suggestions during the course of this work. We also thank Adrian Tsang for technical advice. We gratefully acknowledge NSERC and FRSQ for financial support. Funding for the image analysis system was provided by the Canadian Network for Neural Regeneration and Functional Recovery.

Correspondence should be addressed to Dr. Lisa McKerracher, Centre for Research in Neuroscience, Montreal General Hospital, Livingston Hall, 1650 Cedar Avenue, Montreal, Quebec H3G 1A4, Canada.

Copyright (C) 1993 Society for Neuroscience $0270-6474 / 93 / 132617-10 \$ 05.00 / 0$ tubulin mRNAs (Hoffman and Cleveland, 1988; Tetzlaff et al., 1988, 1991; Hoffman, 1989; Miller et al., 1989; Oblinger et al., 1989). Faster rates of tubulin transport are also correlated with axonal regeneration (Grafstein and Murray, 1969; Grafstein, 1986, 1991; McKerracher et al., 1990a; McQuarrie and Jacob, 1991). In contrast to these changes in tubulin expression, neurofilament (NF) mRNA levels fall in regenerating peripheral nerves (Hoffman et al., 1987; Wong and Oblinger, 1987; Hoffman and Cleveland, 1988; Tetzlaff et al., 1991). Tubulin and NF mRNA levels are believed to influence the axonal cytoskcletal content and the cytoskeletal reorganization required for axonal regrowth. Other events may also play a role in regulating the axonal cytoskeleton, such as protein phosphorylation (Nixon and Logvinenko, 1986; De Waegh et al., 1992).

While such changes in the regulation of the cytoskeleton have been described in axotomized neurons that regenerate naturally, there are differences in the expression of cytoskeletal proteins after injury to nerve cells that do not regrow in the CNS environment (McKerracher et al., 1990b; Tetzlaff et al., 1991; McKerracher and Hirscheimer, 1992). To investigate molecular changes in tubulin and NF expression after injury in the CNS, retinal ganglion cells (RGCs) were examined after cutting their axons in the optic nerve because several degenerative and regenerative responses have been well characterized in this CNS neuronal projection (reviewed by Aguayo et al., 199 Ia,b).

We cxamined the mRNA levels for $\beta$-tubulin and the 150 $\mathrm{kDa}$ NF subunit (NF-M) in RGCs at various times after transection of the optic nerve $9 \mathrm{~mm}$ from the eye. Because the RGCs represent less than $2 \%$ of the neuronal population in the retina, and many of the RGCs die after axotomy (Villegas-Perez et al., 1988; Aguayo et al., 1991b), we have also determined mRNA levels by in situ hybridization. We report here that the temporal changes in tubulin and NF-M mRNA levels differ after axotomy, and discuss these findings in relation to previously studied alterations in axonal transport following RGC injury in the optic nerve (McKerracher et al., 1990b).

\section{Materials and Methods}

Hybridization probes. A tubulin cDNA clone of 1.2 kilobases $(\mathrm{kb})$ in pBR322 to the mouse $\beta$-tubulin gene $m \beta 5$ (Lewis et al., 1985) was obtained from Dr. Donald Cleveland (Department of Biological Chemistry, Johns Hopkins University). Three subclones were generated in Bluescript vectors containing an 826 base pair (bp) KpnI fragment, a $750 \mathrm{bp}$ HincII fragment, and a $652 \mathrm{bp}$ PvuII fragment. All of these fragments span regions conserved between separate $\beta$-tubulin isotypes, and were found to hybridize with other tubulin isotypes expressed in retina (see Fig. 2). The HinclI fragment was used for most experiments. 
A

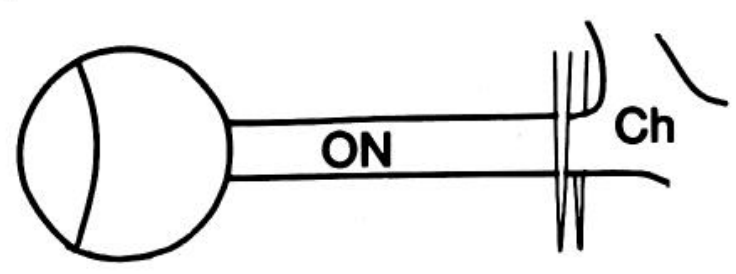

B

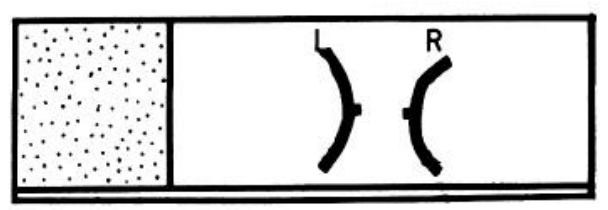

Figure 1. Schematic representation of the optic nerve transection and preparation of the retina for analysis of the axotomized RGCs. $A$, The optic nerve $(O N)$ was transected $9 \mathrm{~mm}$ from the eye rostral to the chiasma $(C h) . B$, Both the axotomized and contralateral retinas were sectioned together to standardize section thickness, hybridization conditions, and emulsion thickness for intact and axotomized retinas.

A 660 bp fragment of the mouse NF-M gene (Julien et al., 1986) was provided by Dr. Jean-Pierre Julien (Centre for Research in Neuroscience, McGill University).

Hybridization probes of both sense and antisense orientations were generated by in vitro transcription from linearized probes with reagents from Stratagene (La Jolla, CA) and ${ }^{35}$ S-UTP (New England Nuclear). The labeled RNA was purified by phenol/chloroform extraction and ethanol precipitation before use.

Surgical procedures. Adult female Sprague-Dawley rats, 180-220 gm, were anesthetized before surgery with an intraperitoneal injection of $0.42 \mathrm{mg} / \mathrm{gm}$ body weight chloral hydrate. In 13 rats the left optic nerve was exposed intracranially by aspirating a small portion of the left frontal lobe, and the optic nerve was cut with small scissors rostral to the chiasma, approximately $9 \mathrm{~mm}$ from the eye (Fig. 1). In three other rats the optic nerve was crushed with forceps. Labeling of RGCs with fast blue or DAPI was carried out as described previously (McKerracher et al., 1989).

RNA blots. The procedure of Chomczynski and Sacchi (1987) was used to prepare RNA from four to six retinas $2 \mathrm{~d}, 2$ weeks, or 1 month after optic nerve transection. The retinas were homogenized immediately in $1 \mathrm{ml}$ of $4 \mathrm{~m}$ guanidinium thiocyanate, $25 \mathrm{~mm}$ sodium citrate, pH $7,0.5 \%$ sarcosyl, 0.1 m 2-mercaptoethanol with a glass-glass homogenizer and brought to a volume of $2 \mathrm{ml}$. Next, $0.1 \mathrm{vol}$ of $2 \mathrm{~m}$ sodium acetate, $\mathrm{pH} \mathrm{4.0,1}$ vol of water-saturated phenol, and $0.2 \mathrm{vol}$ of chloroform-isoamyl alcohol (24:1) were added. The RNA was collected from the aqueous phase after centrifugation, and precipitated with 1 vol of isopropanol. The pellet was dissolved in $0.3 \mathrm{ml}$ of the isothiocyanate solution and the above procedure repeated. Equal amounts of total RNA were electrophoresed on agarose-formaldehyde gels, transferred to $\mathrm{Ny}$ tran membranes (Schleicher and Schuell, Keene, NH), and hybridized with approximately $10^{6} \mathrm{cpm} / \mathrm{ml}{ }^{32} \mathrm{P}$-labeled RNA probes in hybridization buffer (see below) at $65^{\circ} \mathrm{C}$. The blots were washed to a stringency of $0.1 \times$ saline-sodium citrate (SSC), $0.1 \% \mathrm{SDS}$ at $75^{\circ} \mathrm{C}$ for $30 \mathrm{~min}$.

In situ hybridization. The eyes were removed at $18 \mathrm{hr}(n=3$ animals), $2 \mathrm{~d}(n=2), 1$ week $(n=2), 2$ weeks $(n=3), 1$ month $(n=2)$, or 6 months $(n=1)$ after optic nerve transection, or 2 weeks $(n=2)$ or 1 month $(n=1)$ after optic nerve crush. The retinas were fixed in $4 \%$

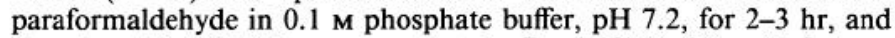
then rinsed in PBS (10 mM phosphate buffer, $0.9 \% \mathrm{NaCl}$ ) and left overnight in $10 \%$ sucrose in PBS. All solutions from this step to the posthybridization rinses were made RNase-free. The axotomized and contralateral control retinas were frozen and sectioned together to ensure that the section thickness, hybridization procedure, and emulsion did not vary between the intact and axotomized retinal samples (Fig. 1). Sections of 7-10 $\mu \mathrm{m}$ thickness were mounted on coated slides (Rentrop et al., 1986) and stored at $-80^{\circ} \mathrm{C}$ until use. Slides were lyophilized, rinsed in
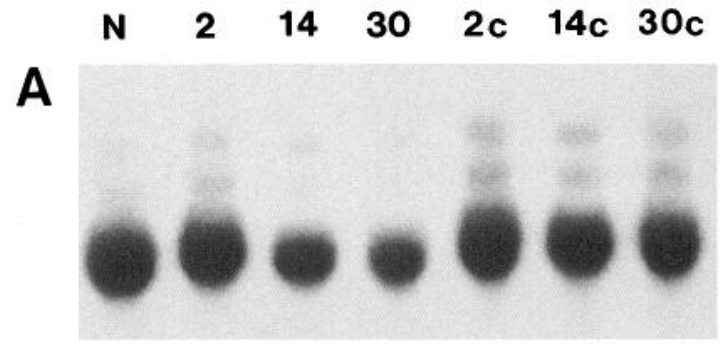

B
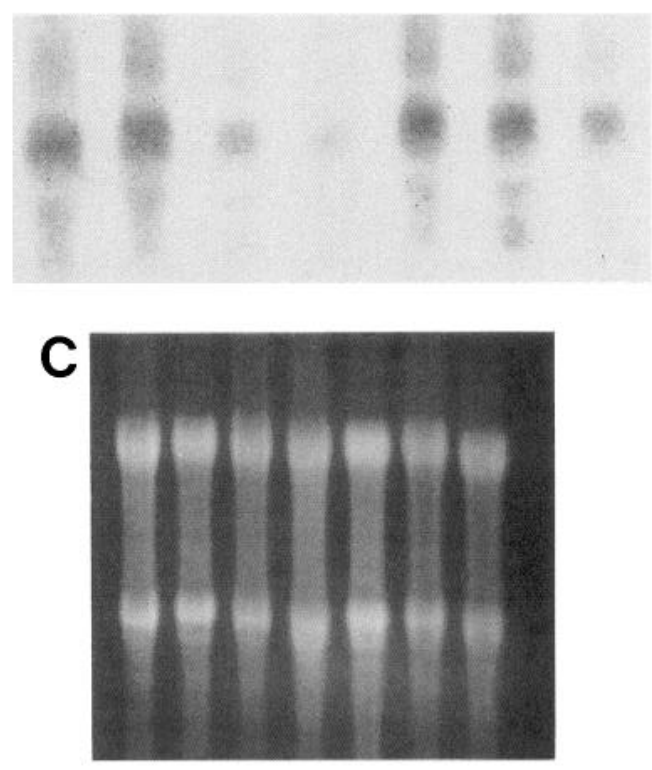

Figure 2. Northern blot analysis of retinal mRNA after axotomy. RNA was prepared from several retinas of unoperated rats $(N)$, and from the left, axotomized eye of rats $2 \mathrm{~d}(2), 2$ weeks (14) or 1 month (30) after axotomy, and the right contralateral retinas $(2 c, 14 c$, and $30 c)$ from the same animals. $A, \mathrm{~A}$ blot hybridized with the $\beta$-tubulin probe. Bands of $3.5,2.9$, and $1.8-2.5 \mathrm{~kb}$ are reduced in intensity by $14 \mathrm{~d}$ after axotomy. $B$, The same blot after it was stripped and reprobed for NF-M. The abundance of the $3.5 \mathrm{~kb}$ NF-M mRNA was reduced after axotomy. $C$, Ethidium bromide staining of the same gel to show the total amount of RNA loaded in each lane.

PBS, and then acetylated in freshly made $100 \mathrm{~mm}$ triethanolamine, $\mathrm{pH}$ $7,0.25 \%$ acetic anhydride. After rinsing in PBS the slides were prehybridized for $1 \mathrm{hr}$ in the hybridization buffer [ $2 \times \mathrm{SSC}, 50 \%$ formamide, $10 \mathrm{~mm}$ dithiothreitol (DTT), $250 \mu \mathrm{g} / \mathrm{ml}$ each of yeast tRNA and sheared salmon sperm DNA, $1 \times$ Denhardt's (Sigma, St. Louis, MO) $5 \mathrm{~mm}$ EDTA pH 8 , and $2 \%$ SDS]. The hybridization was for $18 \mathrm{hr}$ in $50 \mu \mathrm{l}$ of hybridization buffer with $10^{6} \mathrm{cpm}$ of ${ }^{35} \mathrm{~S}$-labeled probe at $45-50^{\circ} \mathrm{C}$. The slides were washed in $4 \times$ SSC, $10 \mathrm{~mm}$ DTT twice, and then $4 \times$ SSC $2 \times 10 \mathrm{~min}$ and treated with $50 \mu \mathrm{g} / \mathrm{ml} \mathrm{RNase} \mathrm{A} \mathrm{in} 5 \mathrm{~mm}$ EDTA, $0.5 \mathrm{~mm} \mathrm{NaCl}, 10 \mathrm{~mm}$ Tris, $\mathrm{pH}$. The slides were washed in decreasing concentrations of SSC at $65^{\circ} \mathrm{C}$ over a period of $2 \mathrm{hr}$. The final $30 \mathrm{~min}$ wash in $0.1 \times \mathrm{SSC}$ was at room temperature, or at $65^{\circ} \mathrm{C}$ for some experiments with NF-M. The slides were dipped in a 1:1 dilution of Kodak NTB2 emulsion at $45^{\circ} \mathrm{C}$ and developed several days later for $5 \mathrm{~min}$ in Kodak D19 diluted 1:1 with water.

Other methods. Slides were viewed before staining and photographed for dark-field microscopy. After staining for $5 \mathrm{~min}$ in $0.25 \%$ thionin (Sigma, St. Louis MO), $0.1 \mathrm{~m}$ sodium acetate, $\mathrm{pH} \mathrm{4,} \mathrm{the} \mathrm{slides} \mathrm{were}$ rapidly rinsed in water, dried, and coverslipped with DPX (BDH Inc., Toronto, Ontario). The cell size and number of grains over each cell were determined from the central region of each retina with the aid of an image analysis system obtained from Empix Imaging (Mississauaga, Ontario) and IMAGE 1 software (Universal Imaging Corp., West Chester, PA). All RGC layer cells observed along the length of retina examined were scored if they were larger than approximately $50 \mu \mathrm{m}^{2}$, and were not darkly staining and elongate, with 50-150 cells counted for each of the two retinal sections per slide. Three to six experiments were analyzed for each time point (see Fig. $8 A, B$ ) or treatment (see Fig. 9). The RGCs 

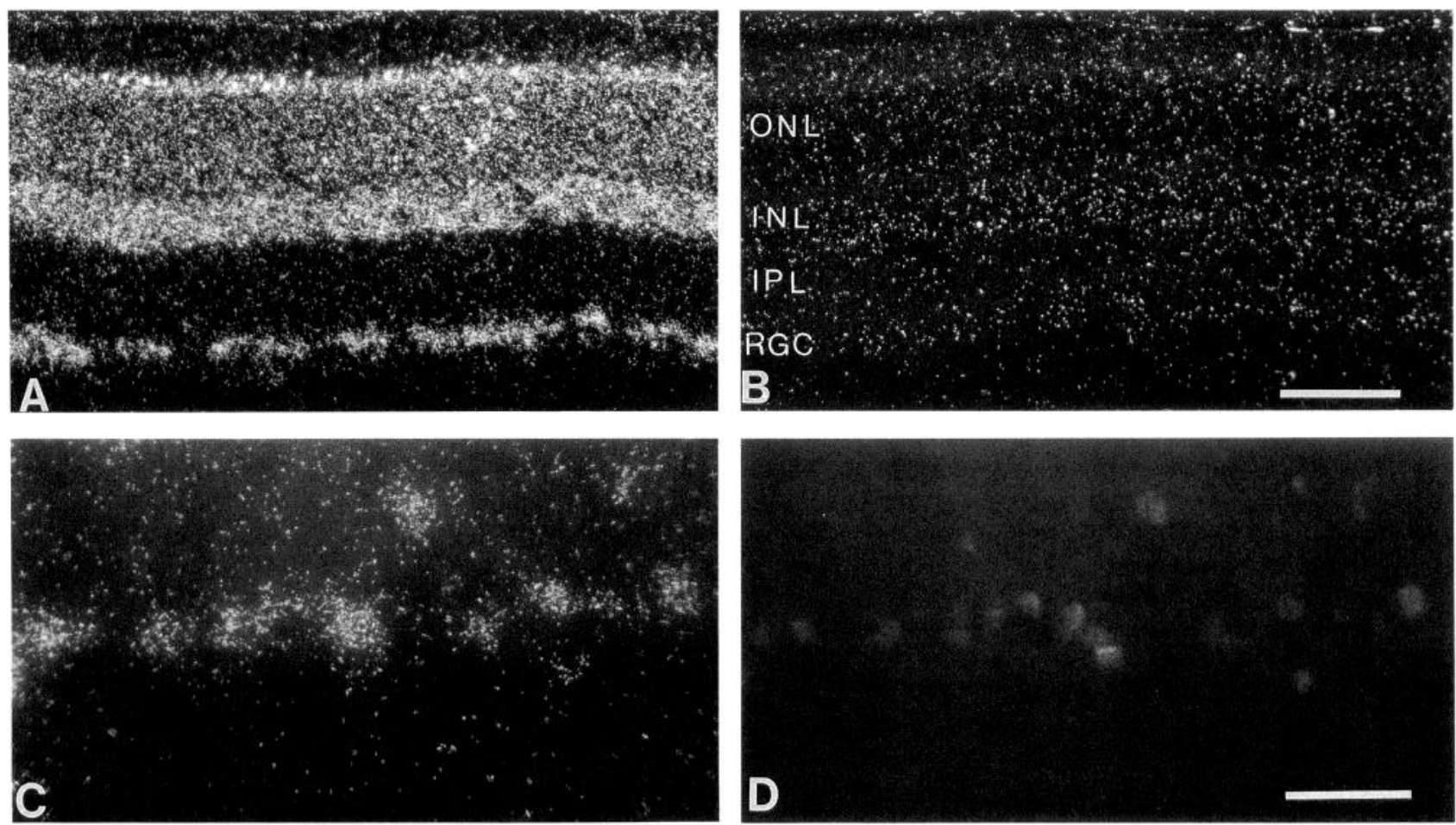

Figure 3. Control experiments with the NF-M probe. Retinal sections were hybridized with the antisense $(A)$ or sense $(B)$ RNA probes. The antisense probe labels the RGC layer $(R G C)$, amacrine cells in the inner nuclear layer $(I N L)$, and photoreceptor nuclei in the outer nuclear layer $(O N L)$. The dendritic processes in the inner plexiform layer $(I P L)$ are not labeled. Only background labeling was present when the sense probe was used. $C$ and $D$, Dark-field microscopy $(C)$ and DAPI staining $(D)$ of the same section show that all of the cells in the RGC layer express NF-M. Scale bars: $A$ and $B, 100 \mu \mathrm{m} ; C$ and $D, 50 \mu \mathrm{m}$.

were identified on the basis of their large cell size (Perry, 1981; Beale and Osborne, 1982), and the number of grains per cell was averaged for the cells larger than $70 \mu \mathrm{m}^{2}$ for each experiment. Data manipulation and graphics were using the software program Axum (TriMetrix Inc., Seattle, WA).

\section{Results}

\section{Northern blots of normal and axotomized retinal $R N A$}

To examine the expression of tubulin and NF after injury in the CNS, the levels of mRNA encoding $\beta$-tubulin and NF-M were studied in the retina after cutting the RGC axons in the optic nerve (Fig. 1). RNA from axotomized retina and the intact contralateral retina was separated electrophoretically before preparing blots for hybridization with ${ }^{32} \mathrm{P}$-labeled RNA probes. Hybridization of the blots with an HincII fragment of $\beta$-tubulin, with extensive sequence homology to all $\beta$-tubulin isotypes, resulted in the same hybridization pattern found in brain (not shown), with a major band of $1.8-2.5 \mathrm{~kb}$, and two minor bands of $2.9 \mathrm{~kb}$ and $3.5 \mathrm{~kb}$. Hybridization of the retinal blots with the NF-M probe labeled the $3.5 \mathrm{~kb}$ RNA species found in brain. These blots demonstrated that the proportion of $\beta$-tubulin and NF-M mRNA to the total retinal RNA decreased after axotomy (Fig. 2). This could result either from the RGC loss that follows axotomy, or from changes in the pattern of RNA expression in the surviving cells. To distinguish between these possibilities, tubulin and NF mRNA levels were examined in individual cells by in situ hybridization.

\section{The pattern of $\beta$-tubulin and NF-M expression in normal and injured retina}

Several controls were performed to show that the hybridization in situ with the $\beta$-tubulin and NF-M RNA probes was specific.
Sense RNA transcripts were hybridized to sections and compared with antisense RNA labeling on adjacent sections (Fig. $3 A, B)$. A probe encoding opsin, which was expressed only in photoreceptor cells, confirmed the specificity of the hybridization conditions used (not shown). Nonetheless, the extensive expression of NF-M in amacrine cells of the inner nuclear layer (Fig. $3 A$ ) was surprising because NF protein staining has been reported to be absent in this cell class (Shaw and Weber, 1983). To verify that our probe was hybridizing to NF-M, we increased the hybridization stringency, and found that the hybridization signal to amacrine cells was lost under the same conditions as the signal in RGCs (not shown).

To verify that the displaced amacrine cells in the RGC layer expressed NF-M, the cell nuclei were stained with DAPI after autoradiography. All of the RGC layer cells express high levels of NF-M (Fig. $3 C, D$ ). In other experiments, retrograde labeling with fast blue to identify RGCs was compared with the NF-M hybridization signal, and NF-M was expressed in the unlabeled displaced amacrine cells (not shown). Similarly, high levels of $\beta$-tubulin expression were observed in amacrine cells as well.

In control retina, the NF-M hybridization signal was restricted to the RGC layer, inner nuclear layer, and outer nuclear layer, with no extensive labeling in the dendrites within the inner plexiform layer (see Figs. 3,5 ). The probe encoding $\beta$-tubulin gave a similar hybridization pattern (Fig. 4). We compared the signal intensity of hybridization for both $\beta$-tubulin and NF-M in axotomized and intact retinas at various times by dark-field microscopy. Severing the optic nerve damages RGC axons and has no effect on the majority of cells in the retina because retinal interneurons do not project into the optic nerve. In the RGC layer, no dramatic differences in the signal intensity for either 

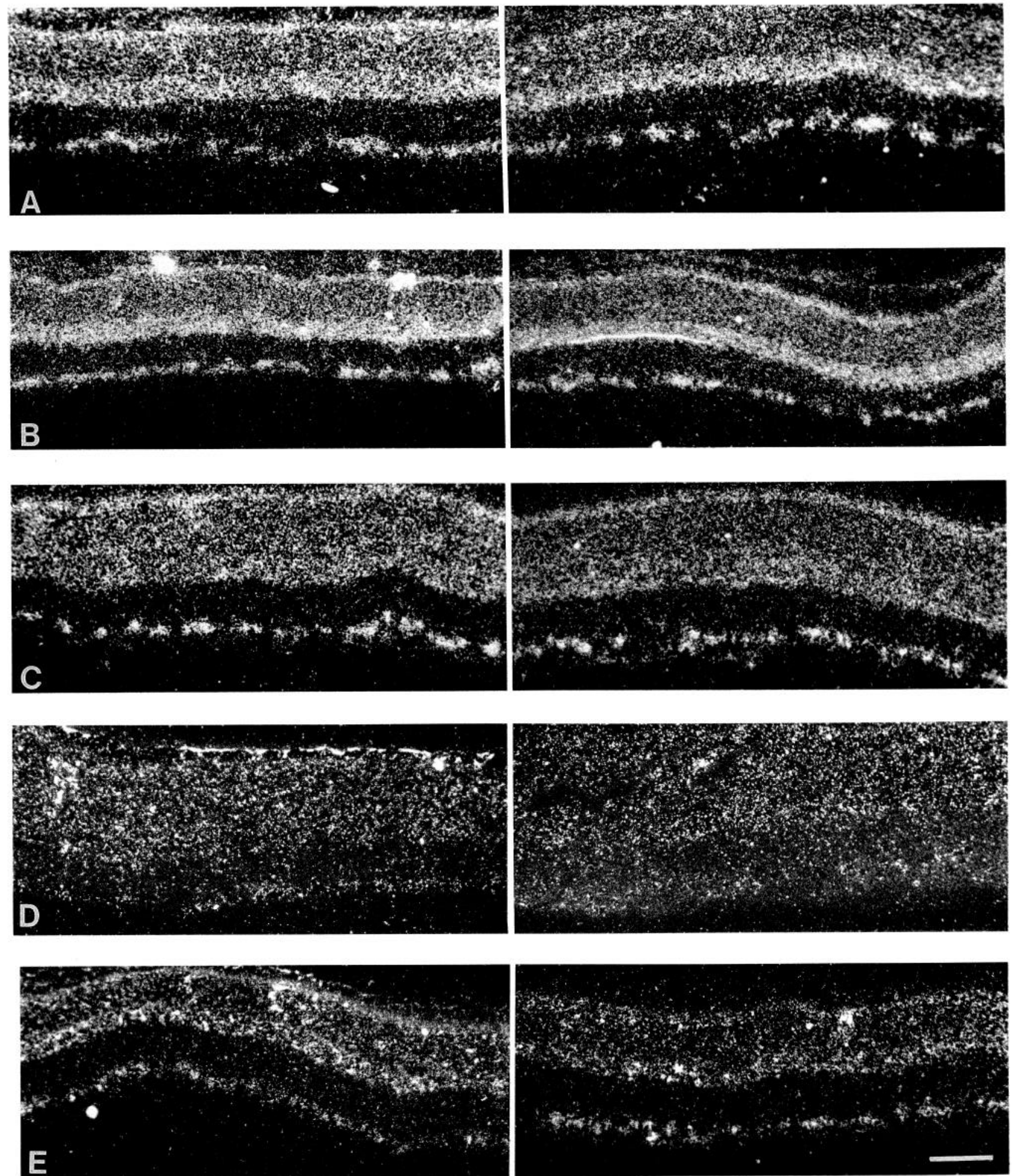

Figure 4. In situ hybridization with the $\beta$-tubulin RNA probe: dark-field micrographs of control (left) and axotomized (right) retinas at $1 \mathrm{~d}(A)$, $2 \mathrm{~d}(B), 1$ week $(C), 2$ weeks $(D)$, and 1 month $(E)$ after injury. See Figure 3 for a description of the retinal layers. Scale bar, $100 \mu \mathrm{m}$.

the $\beta$-tubulin (Fig. 4) or NF-M (Fig. 5) probes were observed in most pairs of control and experimental sections. However, the displaced amacrine cells, which make up $50 \%$ of the cells in the RGC layer, are not directly affected by axotomy. Furthermore, approximately $30 \%$ of the RGCs are lost after intracranial optic nerve crush (Aguayo et al., 1991b), a fact that indicates the limited sensitivity of such qualitative observations.
Quantitative comparison of $m R N A$ levels in axotomized and intact $R G C s$

Single cells were observed at high magnification for computerassisted grain counting. The majority of the grains were localized over the neuronal somata (Fig. 6). For these experiments the grain yield was optimized by varying the exposure time to cover 

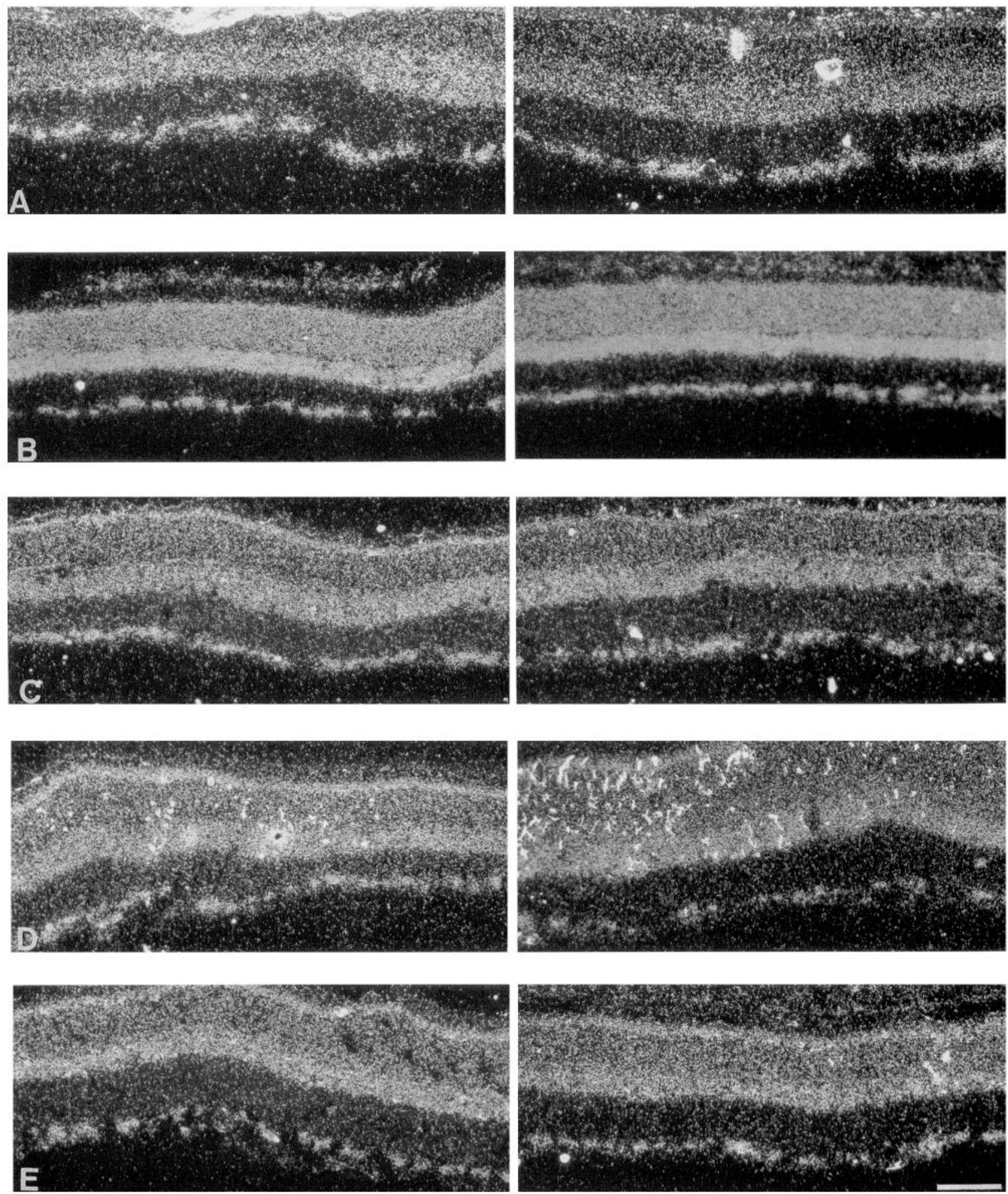

Figure 5. Dark-field micrographs after in situ hybridization with the NF-M probe are shown for control (left) and axotomized (right) retinas. The retinas were processed $1 \mathrm{~d}(A), 2 \mathrm{~d}(B), 1$ week $(C), 2$ weeks $(D)$, and 1 month $(E)$ after optic nerve transection. Scale bar, $100 \mu \mathrm{m}$.

approximately $5-15 \%$ of the cell area. The largest cells expressed the highest levels of both $\beta$-tubulin and NF-M mRNA (Fig. 7). Because it has been well documented that RGCs are larger than displaced amacrine cells (Perry, 1981; Beale and Osborne, 1982), we confined our analysis to ganglion cell layer neurons that were larger than $70 \mu \mathrm{m}^{2}$. Examples of the quantitative analysis completed for each slide are shown in Figure 7.

To examine the temporal pattern of changes in $\beta$-tubulin and NF-M expression after axotomy, the average number of grains counted after axotomy was expressed as a percentage of the 

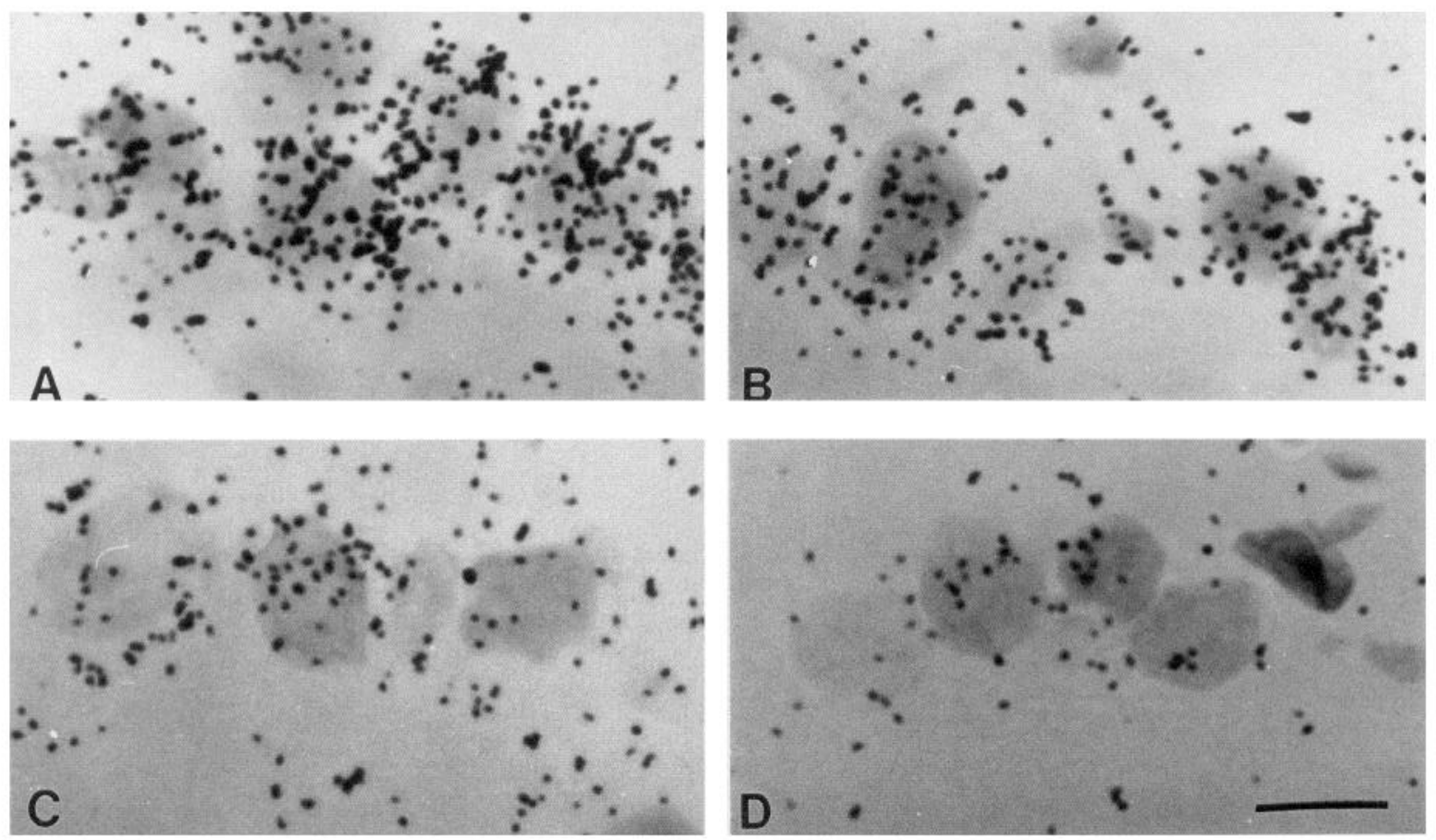

Figure 6. Bright-field micrographs of pairs of control $(A, C)$ and axotomized $(B, D)$ RGC layer cells 2 weeks after injury. Most of the grains were over the cell body regions in the RGC layer after hybridization with $\beta$-tubulin $(A, B)$ or NF-M $(C, D)$. Scale bar, $10 \mu \mathrm{m}$.

control RGC value obtained from the same slide, and the results are shown in Figure 8. The $\beta$-tubulin mRNA level increased to approximately $140 \%$ of the control value $1 \mathrm{~d}$ after axotomy. However, this increase was not sustained, and the $\beta$-tubulin mRNA levels dropped below the control value 1 week after axotomy and did not recover over the 6 month period examined.

In contrast to the temporal pattern of $\beta$-tubulin expression, the NF-M mRNA levels decreased immediately after axotomy. The NF-M mRNA levels remained below normal for the 6 month period.

We examined whether the type of optic nerve lesion influenced the changes in $\beta$-tubulin and NF-M mRNA levels at 2 weeks and 1 month after axotomy. For these experiments the optic nerve was crushed in three animals. While retrograde axonal degeneration and glial cell damage are more severe after optic nerve cut than crush (Richardson, et al., 1982; McKerracher et al., 1990b; Berkelaar et al., 1991), the differences observed between cut and crush lesions after probing RGCs with $\beta$-tubulin (Fig. $9 A$ ) were not statistically significant. Both cut and crush lesions resulted in similar decreases in the NF-M mRNA levels (Fig. 9B).

\section{Discussion}

We have compared the expression of NF-M and $\beta$-tubulin after axotomy of adult rat RGCs. A transient increase in the tubulin mRNA level was observed soon after axotomy but levels fell below normal 1 week after injury. In contrast, the NF-M mRNAs decreased immediately after axotomy. These changes were documented by quantitative autoradiography over identified RGC somata in retinas processed for in situ hybridization. The cell grain counts reflect genuine changes in the injured cells, and not overall decreases in mRNA levels in the retina that could result from the death of many of the axotomized RGCs (Vidal-Sanz et al., 1987; Villegas-Perez et al., 1988, 1993; Aguayo et al., 1991a,b; Berkelaar et al., 1992). Furthermore, because numbers of autoradiographic grains rather than grain density were estimated, the changes documented could not result from alterations in cell size that can follow axotomy (Villegas-Perez et al., 1988).

\section{Intermediate filament expression after axotomy}

The decrease in the mRNA encoding NF-M after axotomy of RGCs occurred by $1 \mathrm{~d}$ after axotomy and was sustained for the entire 6 month period studied. Other studies have indicated that a decrease in both mRNA and protein levels of NF occurs after injury of other classes of neurons (Hoffman et al., 1987; Hoffman and Cleveland, 1988; Tetzlaff et al., 1988, 1991; Oblinger et al., 1989; Muma et al., 1990). From all of these studies on NF expression after axotomy, it is apparent that axotomy induces an early reduction in the expression of NF-M in neurons, irrespective of whether or not they have regrown an axon. In regenerating sensory and motor neurons a decreased level of mRNA encoding NF (Hoffman et al., 1987; Hoffman and Cleveland, 1988) and amount of NF axonally transported (Hoffman et al., 1985) are associated with somatofugal atrophy (Hoffman et al., 1984). However, an increasing body of evidence indicates that the relationship between NF expression and axonal NF content and caliber is complex, and that axonal caliber may also be influenced by the non-neuronal milieu (Nixon and Logvinenko, 1986; Hernandez et al., 1989; Muma et al., 1990; De Waegh et al., 1992). After axotomy in the optic nerve it is not known if the reduced mRNA levels of NF-M, together with a reduced rate of axonal transport would affect the caliber of the surviving RGC axons.

\section{Decreased expression of tubulin 1 week after axonal injury}

The changes in tubulin mRNA at later times are different after RGC axotomy in the optic nerve and following the severing of 


\section{A Tubulln, 1 day}

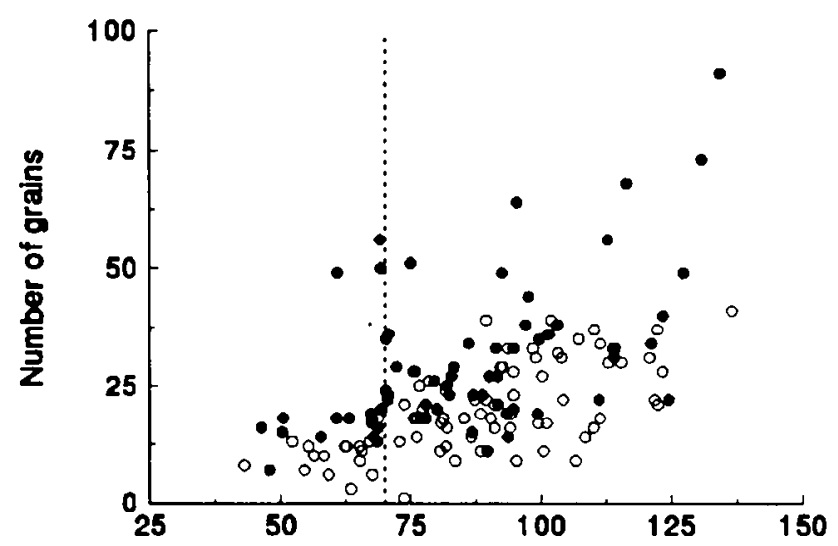

B Tubulin, 1 month

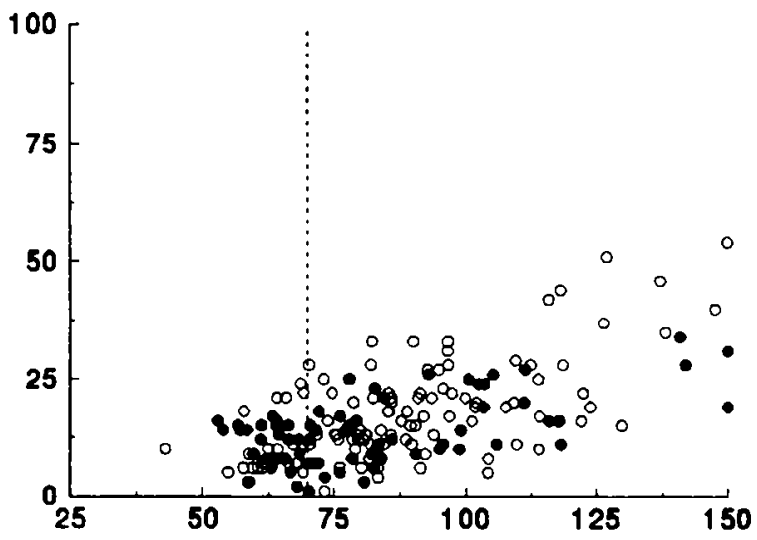

C NF-M, 1 day

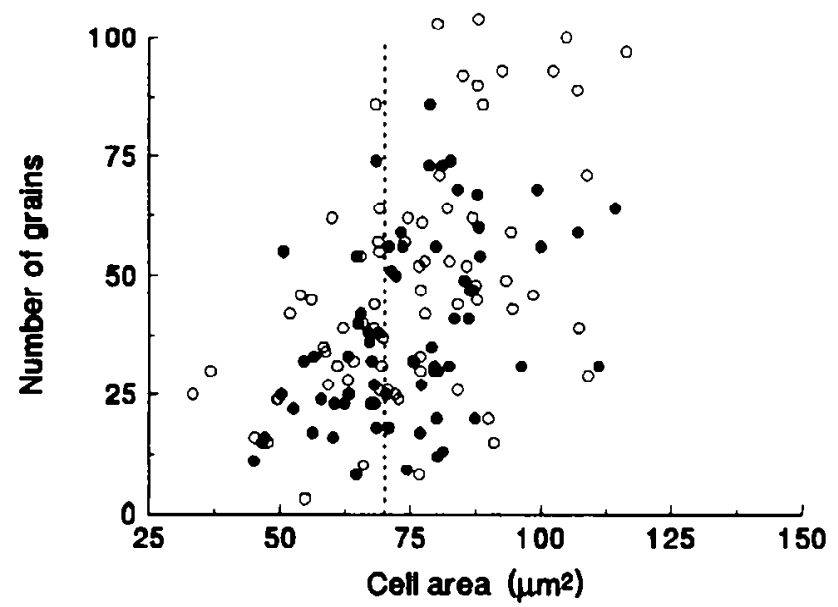

D NF-M, 1 month $\quad 0 \quad 0$

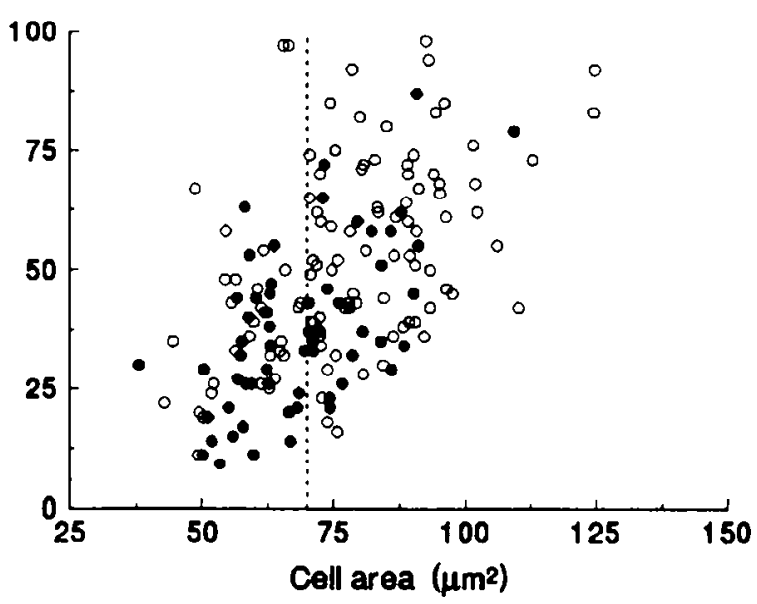

Figure 7. Scatter plots of representative slides hybridized with $\beta$-tubulin $(A, B)$ or NF-M $(C, D) 1 \mathrm{~d}(A, C)$ or 1 month $(B, D)$ after optic nerve transection. Solid circles show the grain counts from axotomized RGCs, and open circles counts from the contralateral intact RGCs on the same slide. The vertical dashed line demarks the $70 \mu \mathrm{m}$ size cutoff used for RGC quantitation.

peripheral nerves (Hoffman and Cleveland, 1988; Tetzlaff et al., 1988, 1991; Hoffman, 1989; Miller et al., 1989). Furthermore, they differ from the changes associated with the interruption of RGC axons in the optic nerve of fish and amphibians (Grafstein, 1986, 1991; Mizobuchi et al., 1990) where axonal regeneration is the rule. It would appear from these and other studies (Aguayo et al., 1991a) that the location of the cell somata in the CNS is not always the determinant of the different neuronal responses to axotomy. Facial nerve axons interrupted within the peripheral nerve environment show a sustained upregulation of $\alpha$-tubulin within the facial nucleus neurons of the pons (Miller et al., 1989; Tetzlaff et al., 1991). In contrast, $\alpha$-tubulin levels decrease in rubrospinal neurons $10 \mathrm{~d}$ after spinal hemisection (Tetzlaff et al., 1991). The present study on RGCs supports and extends these observations to show a decrease in $\beta$-tubulin after injury of these neurons whose somata and axons are confined to the CNS. Moreover, the time course of the $\beta$-tubulin mRNA decrease after optic nerve transection suggests that it is related to alterations in slow axonal transport (see below).
Fall in $\beta$-tubulin, not $N F-M, m R N A$ corresponds with the slowing of axonal transport after axotomy

In the segment of the optic nerve stump that remains attached to the eye after interruption of the optic nerve, the rates of tubulin and NF protein transport decrease 10-fold (McKerracher et al., 1990b; McKerracher and Hirscheimer, 1992). The onset of this change and the reduction of $\beta$-tubulin mRNA reported here occur at the same time of about 1 week after injury. Conversely, the early decrease in NF-M mRNA reported here seems to have no immediate effect on the rate of axonal transport; the drop in the NF mRNA level is immediate, whereas the rate of slow axonal transport in the ocular stump of the optic nerve appears to be unaffected soon after axotomy. Therefore, alterations in the rate of slow axonal transport correlate with the altered expression of tubulin, not of NF.

Despite the temporal correlation between the decrease in tubulin mRNA and the reduced rates of axonal transport after injury in the optic nerve, the tubulin mRNA level only falls by 


\section{A B-tubulin}
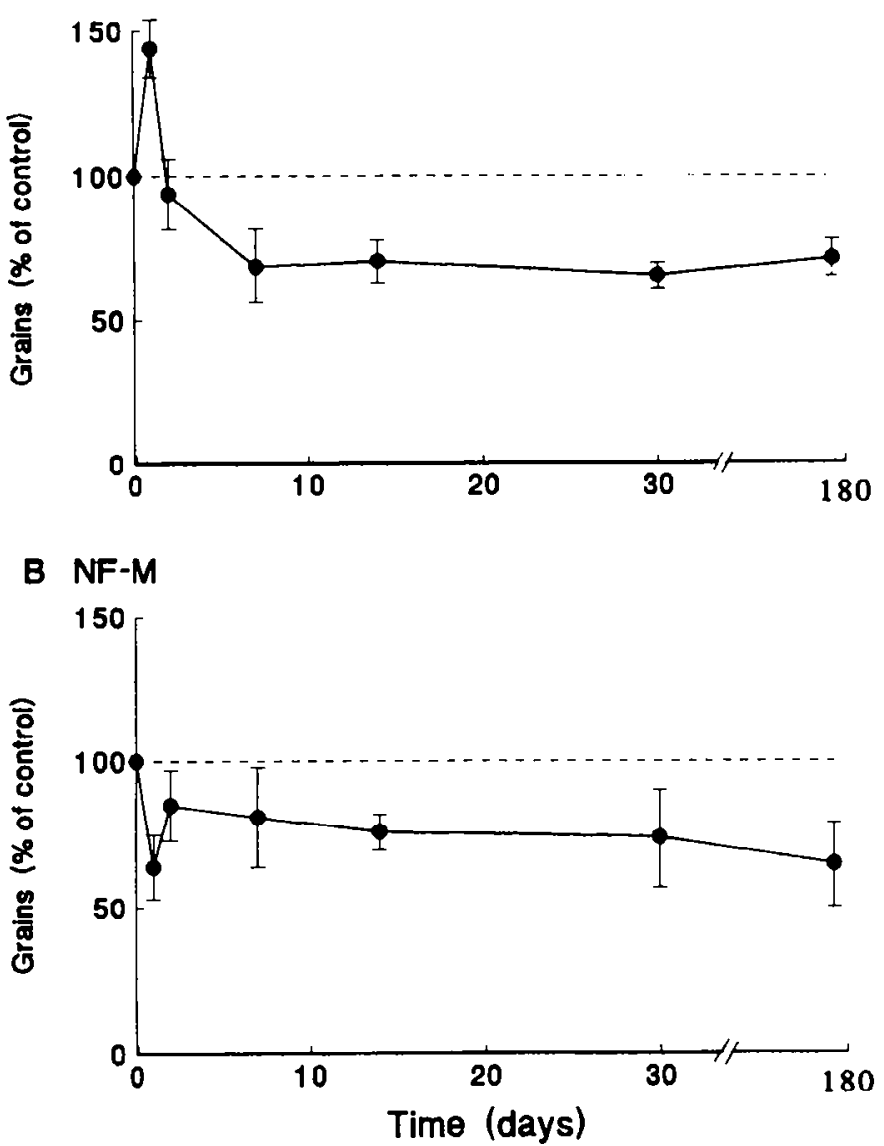

Figure 8. Quantitation of $\beta$-tubulin $(A)$ and NF-M $(B)$ mRNA expression with time after axotomy. The average grain counts from the control and axotomized retinas on each slide were determined for three to five slides from separate experiments for each time point. The SEMs are shown.

approximately $30 \%$ after axotomy. This modest change in the amount of tubulin mRNA suggests that the failure to maintain a normal rate of slow axonal transport after axotomy may not result from the lower level of $m R N A$ encoding tubulin. Rather, the decrease in tubulin mRNA may be a consequence of the failure to export tubulin out of the cell body into the axon. The mRNA levels for $\beta$-tubulin are autoregulated by the tubulin monomer pool (Cleveland et al., 1981) by a sequence present in all of the neuronal $\beta$-tubulin isotypes (Lewis et al., 1985; Theodorakis and Cleveland, 1992). Therefore, the small decrease in mRNA levels after RGC injury may reflect a small increase in free tubulin monomers. If axotomy causes the tubulin monomer level to rise in the cell soma, it is not clear why axonal transport does not continue at the normal rate. It may be that posttranscriptional events are altered by an axonal transection that disrupts the assembly or transport of the axonal cytoskeleton.

\section{The transient increase in tubulin $m R N A$}

Tubulin mRNA levels increased to $140 \%$ of the control within $1 \mathrm{~d}$ after axotomy before dropping below the normal value at I week. Increased tubulin synthesis is closely linked with axonal growth when axons grow in development or during regeneration,

\section{A Tubulin}

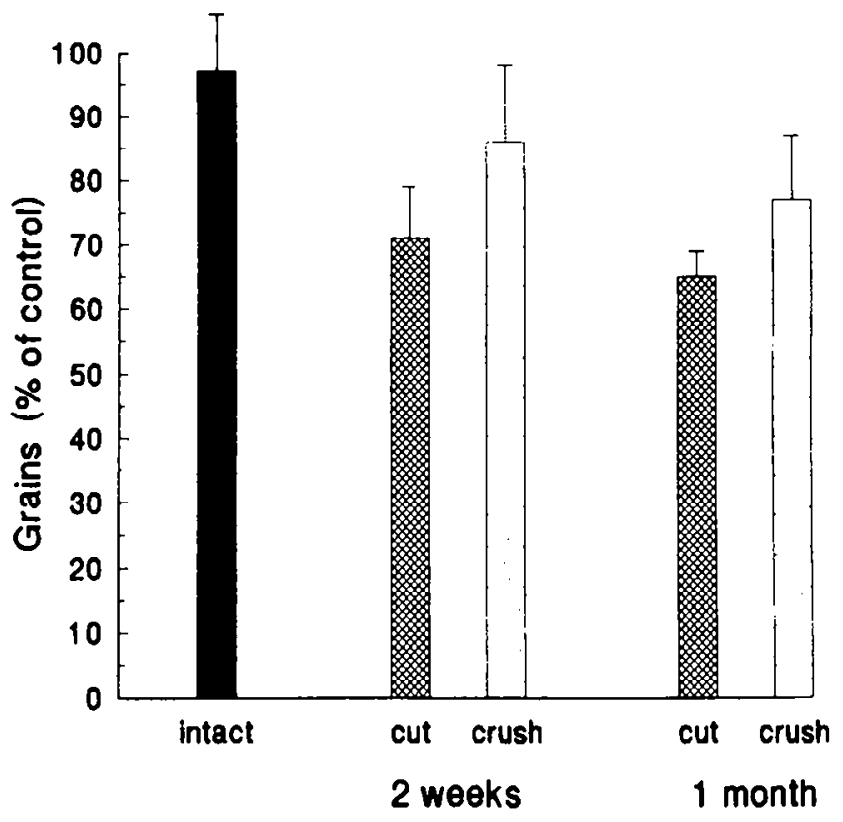

\section{B NF-M}

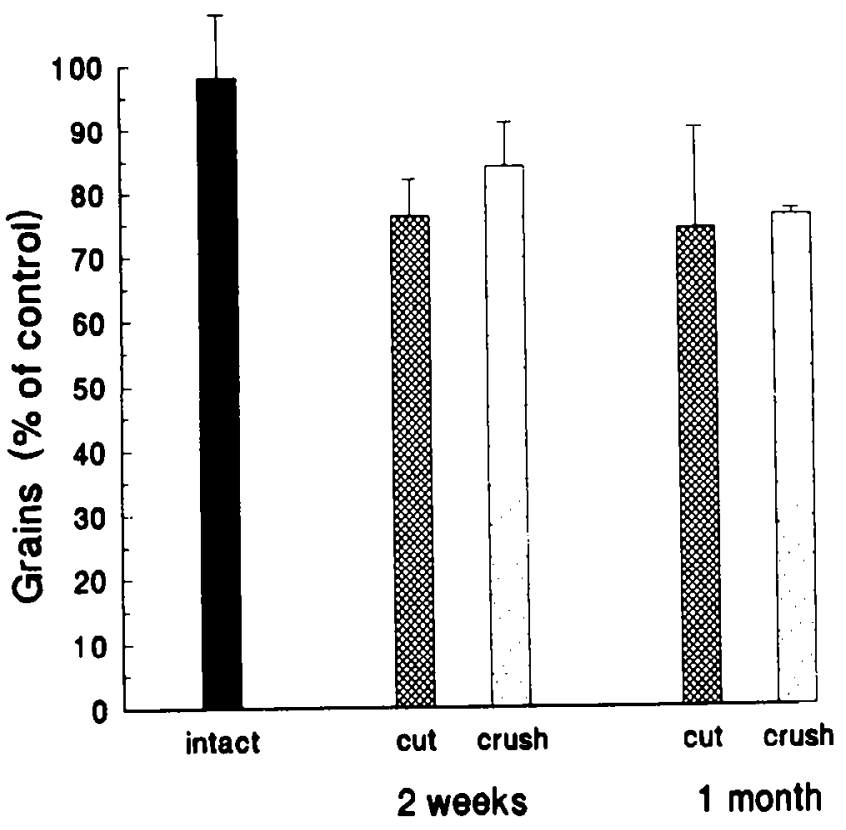

Figure 9. A comparison of cut and crush optic nerve injury on $\beta$-tubulin $(A)$ and NF-M $(B)$ expression 2 weeks or 1 month after axotomy. The intact retina shows a comparison between an intact retrogradely labeled retina and intact unlabeled retina.

as well as during neurite extension in vitro (Grafstein, 1986; Hoffman and Cleveland, 1988; Tetzlaff et al., 1988, 1989; Hoffman, 1989; Miller et al., 1989; Oblinger et al., 1989; Hieber et al., 1992). The results reported here indicate that most, if not all, RGCs may exhibit an initial upregulation of $\beta$-tubulin (see Fig. $7 A$ ). This observation is in agreement with the initial transient response described in axotomized rubrospinal neurons (Tetzlaff et al., 1991). However, a substantial regenerative regrowth does not occur when axons are severed within the optic 
nerve and other CNS regions. Abortive sprouting has been observed after injury of neurons in the CNS, including the optic nerve of adult mammals. Counts of unmyelinated axons by clectron microscopy in injured optic nerves (Richardson et al., 1982) and anterograde labeling studies of RGC axons in transected optic nerves (Giftochristos and David, 1988) indicate that only a few RGC axons grow several micrometers within the injured optic nerve. It is not known if the increased tubulin mRNA expression we observed relates to an early $\mathrm{RGC}$ regrowth that is later aborted, or whether it occurs in the absence of any axonal extension.

After axonal transection, the interactions of the growth cone at the site of the lesion are also important to the early cell body response. An upregulation of tubulin may follow early changes in growth cone-substrate interactions after axonal injury that influence axonal microtubule dynamics. In this case, the upregulation of tubulin could be associated with a transient period of local growth at the site of the injury. Further axonal elongation that depends on the establishment of appropriate growth cone substrate interactions may be needed to sustain the elevatcd tubulin mRNA levels. The increased tubulin expression may not be maintained because axonal regeneration does not normally occur after injury of the optic nerve of mammals.

\section{References}

Aguayo AJ, Rasminsky M, Bray GM, Carbonetto S, McKerracher L, Villegas-Pere $z$ MP, Vidal-Sanz. M, Carter DA (199la) Degenerative and regenerative responses of injured neurons in the central nervous system of adult mammals. Philos Trans R Soc Lond [Biol] 331:337343.

Aguayo AJ, Villegas-Perez MP, McKerracher L, Vidal-Sanz M, Carter D, Bray GM (199lb) Survival, regrowth and reconnection of injured retinal ganglion cells. In: Growth factors and Alzheimer's disease (Hefti F, Will B, Christen Y, eds), pp 15-28. Bcrlin: Springer.

Beale R, Osborne NN (1982) Localization of the Thy-1 antigen to the surfaces of rat retinal ganglion cells. Neurochem Int 4:587-595.

Berkelaar M, Bray GM, Aguayo AJ (1991) Retrograde effects of axotomy by cut or crush of the adult rat optic nerve. Soc Neurosci Abstr 17:555.

Berkelaar M, Cohen A, Bray GM, Aguayo AJ (1992) Effects of optic nerve cut or crush on the short and long-term survival of rat retinal ganglion cells. Soc Neurosci Abstr 18:48.

Chomc7.ynski P, Sacchi N (1987) Single-step method of RNA isolation by acid guanidinium thiocyanate-phenol-chloroform extraction. Anal Biochem 162:156-159.

Cleveland DW, Lopata MA, Sherline P, Kirschner M (1981) Unpolymerized tubulin modulates the level of tubulin mRNAs. Cell 25: $537-546$

De Waegh SM, Lee VM-Y, Brady ST (1992) Local modulation of neurofilament phosphorylation, axonal caliber, and slow axonal transport by myelinating Schwann cells. Cell 68:451-463.

Giftochristos N, David S (1988) Laminin and heparan sulphate proteoglycan in the lesioned adult mammalian central nervous systcm and their possible relationship to axonal sprouting. J Neurocytol 17 : 385-397.

Grafstein B (1986) The retina as a regenerating organ. In: The retina: a model for cell biology studics (Adler R, Farber D, eds), pp 275335. New York: Academic.

Grafstein B (1991) The goldfish visual system as a model for the study of regeneration in the central nervous system. In: Vision and visual dysfunction, Vol 11, Development and plasticity of the visual system (Cronly-Dillon JR, ed), pp 190-205. London: Macmillan.

Grafstein B, Murray M (1969) Transport of protein in goldfish optic nerve during regeneration. Exp Neurol 25:494-508.

Hernandez C, Blackburn E, Alvarez J (1989) Calibre and microtubule content of the non-meduliated and myelinated domains of optic nerve axons of rats. Eur J Neurosci 1:654-658.

Hieber V, Agranoff AW, Goldman D (1992) Target-dependent regulation of retinal nicotinic acetylcholine receptor and tubulin RNAs during optic nerve regeneration in goldfish. J Neurochem 58:10091015.

Hoffman PN (1989) Expression of GAP-43, a rapidly transported growth-associated protcin, and class II beta tubulin, a slowly transported cytoskeletal protein, are coordinated in regenerating neurons. J Neurosci 9:893-897.

Hoffman PN, Cleveland DW (1988) Ncurofilament and tubulin expression recapitulates the developmental program during axonal regeneration: induction of a specific $\beta$-tubulin isotype. Proc Natl Acad Sci USA 85:4530-4533.

Hoffman PN, Griffin JW, Price DL (1984) Control of axonal caliber by neurofilament transport. J Cell Biol 99:705-714.

Hoffman PN, Thompson GW, Griffin JW, Price DL (1985) Changes in ncurofilament transport coincide temporally with alterations in the caliber of axons in regenerating motor fibers. J Cell Biol 101:13321340.

Hoffman PN, Cleveland DW, Griffin JW, Landes PW, Cowan NJ, Price DL (1987) Ncurofilament genc expression: A major determinant of axonal caliber. Proc Natl Acad Sci USA 84:3472-3476.

Julien J-P, Meyer D, Flavell D, Hurst J, Grosveld F (1986) Cloning and developmental expression of the murine neurofilament gene family. Mol Brain Res 1:243-250.

Lewis SA, Gwo-Shu Lee M, Cowan NJ (1985) Five mouse tubulin isotypes and their regulated expression during development. J Cell Biol 101:852-861.

McKerracher L, Hirscheimer A (1992) Slow transport of the cytoskeleton after axonal injury. J Neurobiol 23:568-578.

McKerracher L, Vallee RB, Aguayo AJ (1989) Microtubule-associated protein $1 \mathrm{~A}(\mathrm{MAP}-1 \mathrm{~A})$ is a ganglion cell marker in adult rat retina. Vis Neurosci 2:349-356.

McKerracher L, Vidal-Sanz M, Aguayo AJ (1990a) Slow transport rates of cytoskeletal proteins change during regeneration of axotomized retinal neurons in adult rats. J Neurosci 10:64l-648.

McKerracher L, Vidal-Sanz M, Essagian C, Aguayo AJ (1990b) Selective impairment of slow axonal transport after optic nerve injury in adult rats. J Neurosci 10:2834-2841.

McQuarrie IG, Jacob JM (1991) Conditioning nerve crush accelerates cytoskcletal protein transport in sprouts that form after a subsequent crush. J Comp Neurol 305:139-147.

Miller FD, Tetzlaff W, Bisby MA, Fawcett JW, Milner RJ (1989) Rapid induction of the major embryonic $\alpha$-tubulin mRNA, T $\alpha 1$, during nerve regeneration in adult rats. $J$ Neurosci 9:1452-1463.

Mizobuchi T, Yagi Y, Mizuno A (1990) Changes in $\alpha$-tubulin and actin gene expression during optic nerve regeneration in frog retina. J Neurochem 55:54-59.

Muma NA, Hoffman PN, Slunt HH, Applegate MD, Licberburg I, Price DL (1990) Alterations in levels of mRNAs coding for neurofilament protein subunits during regeneration. Exp Neurol 107:230-235.

Nixon RA, Logvinenko KB (1986) Multiple fates of newly synthesized neurofilament proteins: evidence for a stationary neurofilament network distributed nonuniformly along axons of retinal ganglion cell neurons. J Cell Biol 102:647-659.

Oblinger MM, Szumias RA, Wong J, Liuzzi FJ (1989) Changes in cytoskeletal gene expression affect the composition of regenerating axonal sprouts elaborated by dorsal root ganglion neurons in vivo. J Neurosci 9:2645-2653.

Perry VH (1981) Evidence for an amacrine cell system in the ganglion cell layer of the rat retina. Neuroscience 6:931-944.

Rentrop M, Knapp B, Winter H, Schweizer J (1986) Aminoalkylsilone-treated slides as support for in situ hybridization of keratin cDNAs to frozen tissue sections under varying fixation and pretreatment conditions. Histochem J 18:271-276.

Richardson PM, Issa VMC, Shemie S (1982) Regeneration and retrograde degeneration of axons in optic nerve. J Neurocytol 11:949.

Shaw G, Weber K (1983) The structure and development of the rat retina: an immunofluorescence microscopical study using antibodies specific for intermediate filament protein. Eur J Cell Biol 30:219232.

Tetzlaft W, Bisby MA, Kreutzberg GW (1988) Changes in cytoskcletal proteins in the rat facial nucleus following axotomy. J Neurosci 8:31813189.

Tetzlaff W, Alexander SW, Miller FD, Bisby MA (1991) Response of facial and rubrospinal neurons to axotomy: changes in mRNA expression for cytoskeletal proteins and GAP-43. J Neurosci 11:25282544. 
Theodorakis NG, Cleveland DW (1992) Physical evidence for a cotranslational regulation of $\beta$-tubulin mRNA degradation. Mol Cell Biol 12:791-799.

Vidal-Sanz M, Bray GM, Aguayo AJ (1987) Influence of peripheral nerve grafts on the survival and regrowth of axotomized retinal ganglion cells in the adult rat. J Neurosci 7:2894-2909.

Villegas-Perez MP, Vidal-Sanz M, Bray GM, Aguayo AJ (1988) Influences of peripheral nerve grafts on the survival and regrowth of axotomized retinal ganglion cells in adult rats. J Neurosci 8:265-280.
Villegas-Perez MP, Vidal-Sanz M, Rasminsky M, Bray GM, Aguayo AJ (1993) Rapid and protracted phases of retinal ganglion cell loss following axotomy in the optic nerve of adult rats. J Neurobiol 24: 23-36.

Wong J, Oblinger MM (1987) Changes in neurofilament gene expression occur after axotomy of dorsal root ganglion neurons: an in situ hybridization study. Metab Brain Dis 2:291-303. 